\title{
Prophet without honour: \\ Margaret Butler and \\ the status of sculpture \\ in New Zealand, 1937-40
}

Mark Stocker

Keywords: \# Margaret Butler \# sculpture \# art collecting

\# art criticism \# National Art Gallery

This article consists of two parts, an introductory text,

followed by long-forgotten primary source publications from

1937 to 1940 in the Evening Post, Dominion and Art in New

Zealand. Predominantly letters to the editor, they address

the reputation and profile of the sculptor Margaret Butler

who had returned to her native New Zealand in 1934 after a

prolonged stint overseas. Their authors include the literary

figures Charles Marris and Alan Mulgan. They all note the

critical acclaim she achieved in Paris and Vienna, and the

merits of her sculpture. The writers also ask why native

artistic talent appears to be neglected by institutions such

as the newly-established National Art Gallery in favour of

expensive overseas art, and press for the acquisition of more of Butler's works. No official response was recorded and in

any case Butler's sculptural career had effectively ended by

the time of the last such letter, dated November 1940. 
Margaret Mary Butler (1883-1947) (Figure 1) is a unique sculptural presence in New Zealand. This applies in several respects: she was the first major sculptor born in this country, beating William Thomas Trethewey (1892-1956), a genuine but showier and shallower talent, by almost a decade. ' During her ten-year sojourn in Europe (1923-34), her sculpture received warm praise from world leaders in the field, the Frenchmen Antoine Bourdelle (1861-1929) and Charles Despiau (1875-1946), culminating in an acclaimed solo exhibition at the Galerie Hébrard, Paris (1933). She took sculptural rendition of Māori to a new level of profundity in the works that followed her return to New Zealand, notably La Nouvelle Zélande (c. 1936-38) (Figure 2) and the Māori Madonna (c. 1937-39). ${ }^{2}$ Butler's gender made her ipso facto part of the 'obstacle race' faced by women artists, but a still greater challenge was her disability, especially given the physical nature of sculpture. A serious childhood accident left her with lifelong lameness

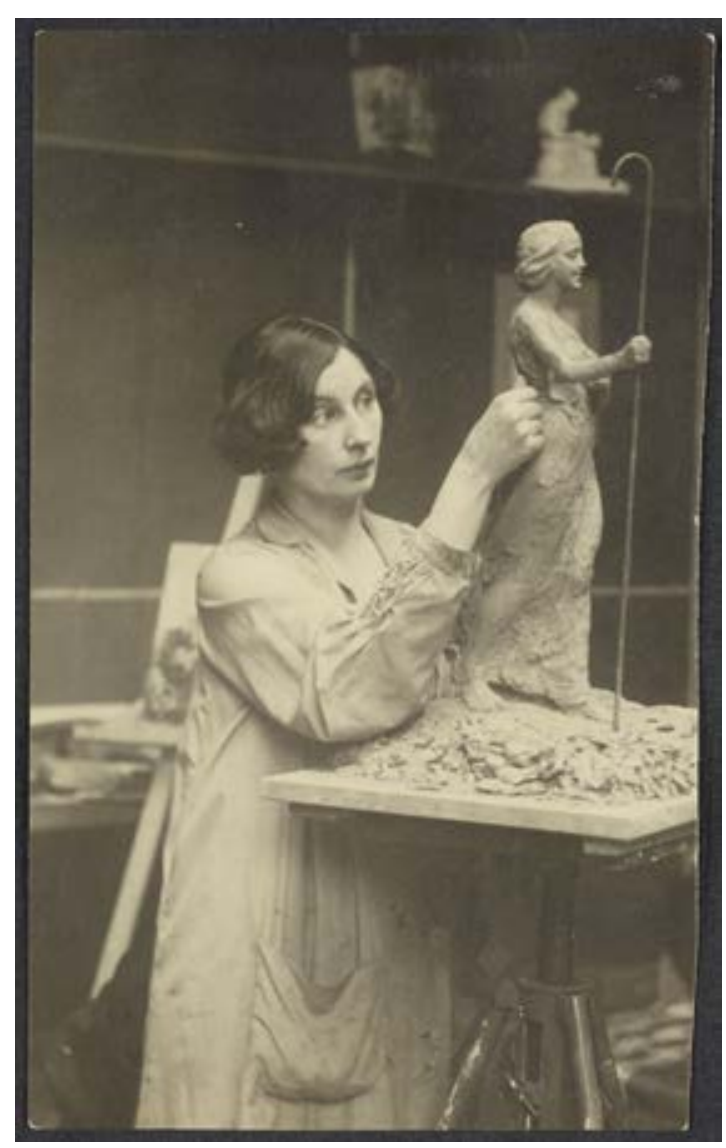

Figure 1: Unknown photographer, Margaret Butler working on the Shepherdess, 1930. Museum of New Zealand Te Papa Tongarewa.

Figure 2: Margaret Butler, La Nouvelle Zélande, 1936-38, bronze, $550 \mathrm{~mm}$ high. Museum of New Zealand Te Papa Tongarewa. Gift of the New Zealand Academy of Fine Arts, 1950 and dependence on her devoted elder sister Mary (d. 1943). Butler's achievement, "a level of sculptural understanding unequalled by any of her New Zealand contemporaries," as Michael Dunn puts it, is thus all the more remarkable. ${ }^{3}$

Yet that feat was - and regrettably still remains - largely unheralded; Butler was "almost forgotten when she died." ${ }^{4}$ In several publications I have attempted to rectify the condescension of posterity and have, moreover, examined her work stylistically. Here I will address the neglect that she faced in the period between her return to $\mathrm{New}$ Zealand (1934) and her effective cessation of sculpture by $1940 .{ }^{5}$ Butler was not without powerful champions: Lord Bledisloe, the GovernorGeneral, declared her 1934 solo exhibition at the New Zealand Academy of Fine Arts "one of the great surprises of my sojourn." And it was a wonderful surprise: "New Zealand had produced a really great sculptor... whatever be her future destiny, our local lady Praxiteles will carry with her the warmest good wishes of her native country."6 Unfortunately for Butler, acclaim from the top did not translate into demand for her sculptures, whether as commissions or as sales of exhibits. Several factors explain this. In the art world at the time, sculpture did not enjoy high status as a medium. Butler's contemporary in Christchurch, Francis Shurrock (1887-1977), ruefully observed that "if you didn't do painting you weren't an artist."7 The economic depression of the early 1930s was still severe at the time of Butler's return, restricting potential commissions. Furthermore, there was little support from the Roman Catholic Church, of which Butler was a devout communicant. Economic circumstances meant that the Church accorded 'good works' priority over artworks. Moreover, it lacked artistic sophistication. The late Michael King believed that "both the material and artistic poverty of the Catholic Church... accounts for the lack of interest in somebody as gifted as Margaret Butler. In the time I grew up [in the years immediately after Butler's death], anyone Catholic who knew anything about art despaired of the church's philistinism at the institutional level."

Butler's admirers deplored the absence of support where it might have been reasonably expected from another institution the National Art Gallery, established by Act of Parliament in 1930. It opened to the public in purpose-built accommodation, shared with the Dominion Museum, in 1936. However, for its first decade the gallery lacked a reliable source of acquisition funds. It was further hampered by the reluctance of the New Zealand Academy of Fine Arts, effectively the gallery's controlling body, to acquire works by living New Zealand 
artists. The National Art Gallery's Centennial Exhibition of International and New Zealand Art in 1939-40 was dominated by the former-

'International'. The gallery felt "its part in celebrating the cultural advancement of New Zealand... could best be carried out by bringing the public into direct contact with the works of eminent contemporary painters overseas as well as those of their own country." 'Eminent' usually meant academically inclined artists; 'overseas' meant, almost invariably, Britain; and 'painters' implicitly excluded sculptors like Butler. Her admirers naturally stressed her overseas reputation in arguing her case, but the official response, other than the acquisition of one work, the bronze head Berto in 1939, was negligible. Art historians have tended to focus on the National Art Gallery's failure to acquire works by Colin McCahon and Toss Woollaston in later decades, but the neglect of native talent, Butler included, long precedes this.

A remarkable sequence of articles and letters to the editors of the Evening Post and Dominion in February and March 1937 championed Butler and amounted to something of a campaign on her behalf. A catalyst for this was the opening of the National Art Gallery almost exactly a year earlier, and a sense that expectations had not been met. Subsequent writings carrying a similar message were published in Art in New Zealand and the Dominion in 1939, and two further relevant items appeared in 1940. Although several were written under noms de plume, a particularly tantalising one being the impassioned 'B.W.S.', their authorship is sometimes traceable. The most prominent supporter was journalist and broadcaster Alan Mulgan (1881-1962); ${ }^{10}$ 'Prester John' was Mulgan's friend, the prolific journalist, editor and anthologist, Charles Marris (1876-1947); ${ }^{11}$ while Haitaitai resident Mark Levy was a member of the Civic League and the New Zealand Academy of Fine Arts, and is sometimes featured in the social pages of Wellington newspapers. These writings form the core of this article; taken together, they constitute a powerful plea for Butler and for the wider recognition of sculpture. Despite this, there appears to have been no published answer from any National Art Gallery or New Zealand Academy of Fine Arts representative.

Butler's attitude towards all the well-meant publicity in any case seems equivocal. She was always the more private of the two sisters. Mary was far more outgoing, and enjoyed a certain reputation in Wellington society for her charming performances as a diseuse or dramatic monologist. ${ }^{2}$ Such attention probably suited the more reserved Margaret, who was happy to see her sister shine in a complementary medium. In a letter to the poet Eileen Duggan
(1894-1972), who later became her close friend, Butler wrote: “The article about me \& my work... was too kind... It made me feel very shy \& fearful to disappoint. Limelight is necessary for actors but for such as me I think it is harmful. So you can see I am writing as much to scold as to thank."13 By the time of the final letter, November 1940, Butler's last significant recorded sculpture, a plaque commemorating the biologist Professor Harry Kirk, had just been unveiled. In early 1942, she and Mary moved to Rotorua for health reasons. Mary's unexpected death there in October 1943 was a severe blow to Margaret and is documented in several pathetic letters to Duggan, one of which states:

To think about my work is an agony, there are so many things I wish to do, but pain \& weakness, even if I had a suitable place to work in make it impossible ... I wanted to retire into a convent after Mary's death... but there was no place for me ... It would seem Our Lord had no need of my work \& so I have been allowed to perish. So be it... ${ }^{14}$

Margaret Butler died of cancer in December 1947. The wish expressed by her admirers, that her sculpture should be acquired by the nation, did belatedly materialise. She bequeathed her studio contents to the New Zealand Academy of Fine Arts which, after exhibiting 28 works in August 1950, ${ }^{15}$ transferred them to the National Art Gallery, forerunner of the Museum of New Zealand Te Papa Tongarewa. Here they remain in safekeeping, and at least two of them, La Nouvelle Zélande and The Dreamer, a meditative statuette figure, have been periodically exhibited.

\section{ART IN NEW ZEALAND}

\section{[Evening Post (5 February 1937): 6]}

(To the Editor.)

Sir, --Will the day ever dawn when New Zealand learns to accord to her outstanding sons and daughters the appreciation which is their due? An almost utter lack of recognition is meted out to the men and women of this country who have made valuable contributions to the world of art and letters. New Zealand-born artists who have created considerable stir at Home [the UK] and abroad have scarcely caused a ripple of interest 
in the land of their birth. One perhaps expects a very young country to neglect the arts, but New Zealand is reaching years of discretion and the time is ripe for her to pay a little more attention to the aesthetic side of life, and take her just place among the cultured nations.

It comes as a surprise to see in the [National] Art Gallery that examples of Miss Margaret Butler's work are only lent. Surely it would be to our advantage to secure them for the city. At least, let us make certain of retaining the bronze "Rosalie," (Figure 3) for only an inspired hand could recapture the pathos of such sorrow and resignation. ${ }^{16}$ Are there no public-spirited men and women here who would act as patrons of art? The Old World seems to have managed these things better. Much beautiful music and many lovely pictures would have been lost to us if patrons had failed to come forward to aid and encourage. It would be superfluous to point out the vital and civilising effect of beauty upon mankind, but it is indeed necessary to draw attention to the fact that creators of beauty here are not allowed to languish in obscurity, if not actual starvation.

It is difficult to understand why in New Zealand art galleries' preference is given to loans from overseas rather than to first class work by New Zealanders.

In the Wellington Gallery space has been afforded to pictures that would stand no chance in an English or Continental exhibition. When limited funds must be considered there might be some excuse for a young and growing gallery to include inferior work in a collection, if none other were to be had, but when talented local artists whose demands are not exorbitant are knocking at the door, this explanation is valueless...

MRS. E. CONNORS.

\section{ART IN NEW ZEALAND}

\section{[Evening Post (9 February 1937): 8]}

(To the Editor.)

Sir, --It is, I must confess, difficult to understand the neglect of Miss Margaret Butler's work referred to by your able correspondent... The only explanation I can suggest is that those responsible for our art exhibitions have never heard of her, or, if they have... they have never seen her work. This would also explain the absence of her productions from the works of art to be sent to London for exhibition at the Royal Institute Galleries, Piccadilly, during the Coronation celebrations in May. ${ }^{17}$

According to the published reports, this exhibition is being organised by the Council of the Royal British Colonial Society of Artists and is to be fully representative not of any particular school of art group, but of the contemporary art of the five Dominions. Now we learn that the New Zealand Committee of Selection are shipping 32 paintings, water-colours, and drawings, but apparently no sculpture. The invitation of the British Society was surely wide enough to embrace all kinds of

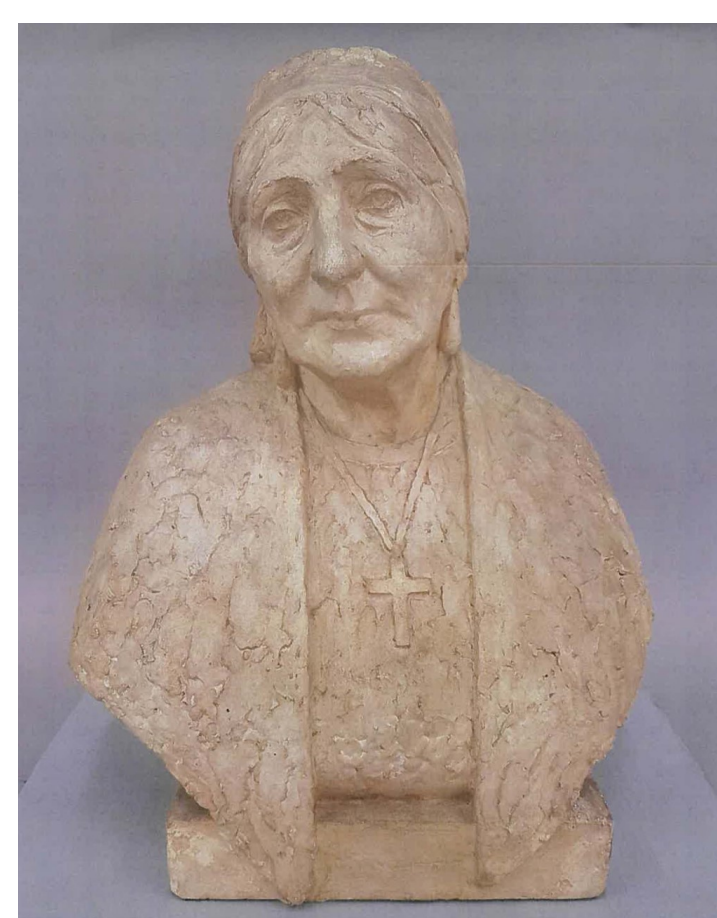

Figure 3: Margaret Butler, Rosalie (Paris), 1930 plaster, $588 \mathrm{~mm}$ high. Museum of New Zealand Te Papa Tongarewa. Gift or the Academy of Fine Arts, 1950 
art, including sculpture. If Miss Butler's sculpture is absent from any collection of the work of local artists it is not representative of the best that New Zealand can produce.

I have visited most of the important art galleries of the world, and I know that Miss Butler's work will hold its own with that of great contemporary artists in the old world. I happened to be in Paris when there was an exhibition of Miss Butler's work at the Galerie Hebrard. To show how highly her productions appeared to those capable of judging, I am going to quote M. Thebault Sissons [sic], one of the greatest, if not the greatest of all living art critics. ${ }^{18}$ Writing in "Le Temps", he said: "This artist has a real talent for sculpture. She is gifted, very gifted. One visit to her works in the Hebrard Gallery, Rue Royale, proves this. This is not the last we shall hear of this artist, who analyses with penetration all the types of the human species that she portrays." (The translation is mine.)

Perhaps now that attention has been drawn to the matter her work will receive the recognition it deserves, and visitors to our National Gallery will soon have the opportunity of studying the works of our distinguished countrywoman, Miss Margaret Butler...

ART LOVER.

\section{ART IN NEW ZEALAND: MISS BUTLER'S WORK [Evening Post (27 February 1937): 8]}

(To the Editor.)

Sir, --The question is often asked in this country why Rhodes Scholars do not return to New Zealand after they have completed their University courses in England. I think that if one wanted to get the real answer to this problem he could do no better than apply to Miss Margaret Butler, the talented sculptor born in and now resident in Wellington. I have been waiting for those who know more about art and especially sculpture to take up the matter raised by Mrs. E. Connors and by "Art Lover," as I feel satisfied that with the limited knowledge at my command I cannot do justice to my task.
It must be about three years since Miss Butler returned to this, her native land, and gave an exhibition of her work. Anyone with the slightest knowledge of sculpture and especially if he has seen sculpture in the other lands as I have done must have been impressed with the fact that at last New Zealand has produced a real sculptress. And yet what do we find? At the National Art Gallery there is a hall of sculpture and Miss Butler's work is represented by one piece--an immature one executed before she left New Zealand to study--presented by a former president of the academy, the late T. Shailer Weston. ${ }^{19}$ (Figure 4)

I have recently been making inquiries from those in a position to advise me and I understand that when Miss Butler's exhibition took place the academy was short of funds and it did not purchase any of her work. Yet shortly afterwards Mrs. Murray arrived with a collection of paintings by English artists (and they were none the better and none the worse for that) and the academy desiring to purchase a painting from this collection, circularised those interested to raise a su of over $£ 300 .^{20}$ I believe that Miss Butler's most highly-priced pieces cost about £100. In the face of these facts and of the appreciation by M. Thebault Sissons... I say that the public of New Zealand especially of Wellington are entitled to some explanation from the Board of Trustees of the National Art Gallery why an effort has not been made to purchase some of

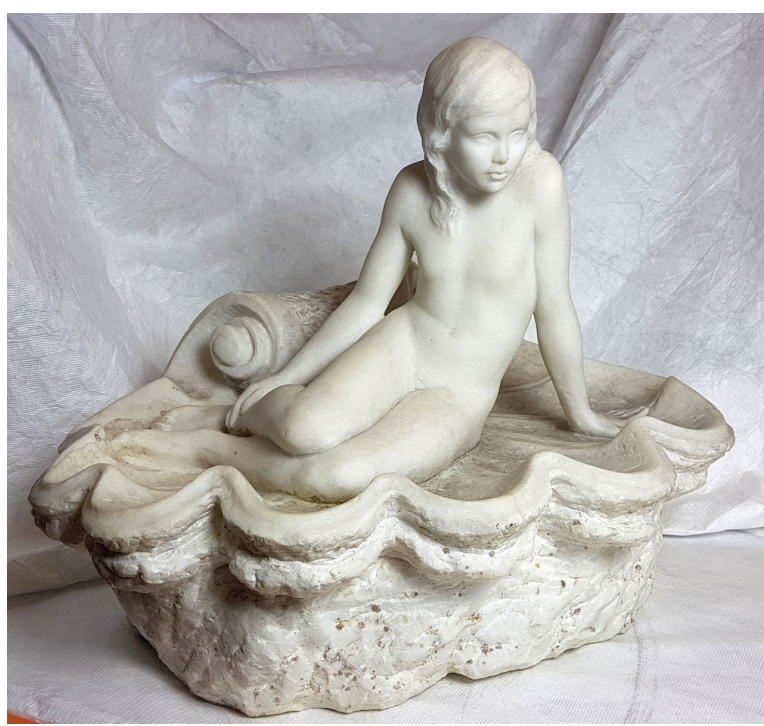

Figure 4: Margaret Butler, Sea Nymph, before 1923, marble, $343 \times 426 \mathrm{~mm}$. Museum of New Zealand Te Papa Tongarewa. Gift of the New Zealand Academy of Fine Arts, 1936. 
her works for exhibition in our Gallery. Everyone recognises that art is international, but when we paid our subscriptions towards the Gallery and Museum we did not think that our own country's artists would be the last to receive recognition.

Another matter upon which the public are entitled to some explanation is the reason for the absence of her sculpture from the works of art to be sent to London for the Royal

Institute Galleries during the Coronation period. Here is a lady who obtained her early art education in this country, who later went abroad and received tuition at the hands of eminent sculptors in Europe, whose work was exhibited every year for eight or nine years at the leading salons in Paris (no mean achievement), and also later at the Royal Academy in London, whose work received most favourable notices from many of the best art critics in Paris, was approved by such great sculptors as Bourdelle, Despiau and [Léon-Ernest] Drivier, and represented photographically in such papers as "L'Art et les Artistes," "la Comoedia," "la Peinture," and in the salon catalogues. Surely in such circumstances one is entitled to expect that at least one piece of Miss Butler's work would have been selected by those in whom the trust of the public is imposed to choose representative works of New Zealand artists for exhibition in London at a time when probably more visitors will be there than on any previous occasion. This matter cannot be allowed to rest where it is, and if the selection committee does not make some explanation of the matter, I propose to write to Viscount Bledisloe, our late Governor-General, to ascertain if possible whether statuary was included (specifically or otherwise) or excluded from the works to be sent to London.

In the course of a long life I have been interested in many matters, but never in one which is so baffling and apparently devoid of any kind of satisfactory explanation. I could understand if the committee selected works concerning which there was doubt as to their merit, but to treat an artist like Miss Butler as if she did not exist is incomprehensible.

It would be very interesting and instructive if the Board of Trustees of the gallery and/or of the selection committee for the London exhibition would state for the information of the public and for the guidance of future aspiring artists the height to which New Zealand-born sculptors must raise or the honour which they must obtain before their work can be accepted for our instruction and pleasure. Is it any wonder that talented New Zealand architects, scientists, etc., are leaving this country and seeking recognition in other lands? --I am, etc.

PERPLEXED.

\section{ART IN NEW ZEALAND \\ [Evening Post (9 March 1937): 8]}

(To the Editor.)

Sir, --The complaint voiced recently in the columns of your paper by "Perplexed" in regard to the lack of recognition given to the work of Miss Margaret Butler, the New Zealand sculptress, as being incomprehensible, is justified. On the other hand, to many experienced judges possessing the necessary qualifying experience and knowledge to pass opinion authoritatively, it is also considered equally incomprehensible why display space is given to some of the exhibits which are to be found, not only in the principal art galleries in the Dominion but are also to be seen the periodical exhibitions held by New Zealand art societies. The function of a selection and hanging committee the world over is an onerous and invidious duty; but there are definite principles laid down according to which they can always set about their task in order to do so without fear or favour. A public art gallery must be regarded as fundamentally an educational medium and as such should contain only works of art which can be regarded as being of a quality worthy of note and exhibition as such or by artists of recognised ability in whose works general interest has been established. Unfortunately this modus operandi is not the invariable policy acted on by all those entrusted with the welfare of New Zealand art. Insufficient discrimination is made in the selection of works offered for exhibition.

If such promising talent as we have in New Zealand is to be led in the right direction... and if those who visit art galleries shall do so with the knowledgeable assurance of having represented before them worthy examples of all that art means, art societies will have to be more selective in the 
appointments to selection and hanging committees in order that the personnel thereof shall be sufficiently possessed of the powers of knowledge and perception.

The reference made by "Perplexed" regarding the fact that most Rhodes scholars do not return to New Zealand after their university courses in England does also apply to New Zealand artists. There is abundant evidence that New Zealand artists (both professional and commercial) not having met with the appreciation and practical support that their work has justified, have left these shores for elsewhere to meet with fuller appreciation and greater practical support towards a sufficient livelihood...

MARK LEVY.

\section{OPEN LETTER TO THE EDITOR AND PUBLISHERS OF ART IN NEW ZEALAND [Art in New Zealand, 38 (June 1937): 195]}

...There is another controversial matter I should like to raise. It is the craze for the imported article, to the neglect of the local product. A typical and outstanding example is Miss Margaret Butler. This young lady, a sculptor, was trained under one of the greatest instructors in France, if not in Europe. ${ }^{21}$ Her best work reveals the outcome of such a training, plus an inherent artistic temperament. Her work is eloquently sensitive in conception and expression. It was sought after by the leading salons of Paris. Nevertheless, Miss Butler is still a prophet without perceptible honour in her own country. One of her latest pieces is the head of an East Coast Māori woman (no depreciating pakeha blood here), which has well-defined classic qualities. ${ }^{22}$ It is the wahine unsophisticated, true to the tribal strain, with striking facial contours and a regal pose. Its price may be the cost of a couple of second-rate imported paintings, but it is worth a dozen of such negligibilities. You will be doing a service to the country if you can persuade the National Gallery to enrich its collection with this noble example of the sculptor's art..

PRESTER JOHN

\section{OURSELVES}

[Art in New Zealand 41 (September 1938): 5]

...Margaret Butler's success in Paris will come as no surprise to those who know the work of this sensitive and clever sculptor. ${ }^{23}$ Margaret Butler had her triumphs overseas before returning to New Zealand after a decade of study in France and Austria, and we hope the time will come when her own country will accord her the recognition that her art deserves...

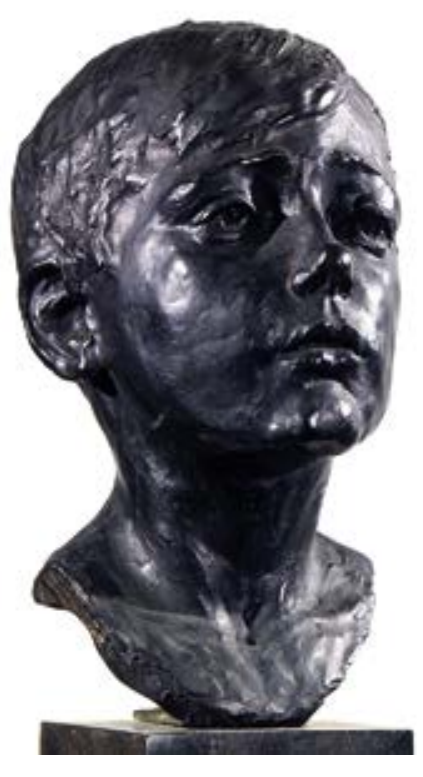

Figure 5: Margaret Butler, Berto, 1928, bronze, c. 1936, $434 \mathrm{~mm}$ high. Museum of New Zealand Te Papa Tongarewa. Gift of the New Zealand Academy of Fine Arts, 1940.

\section{BRILLIANT WORK \\ [Dominion (30 November 1939): 6]}

New Zealand Sculptor's Achievements

MARGARET BUTLER

Lack of Recognition in Own Country (By B.W.S.)

The purchase by the National Art Gallery of a bronze by the Wellington sculptress, Miss Margaret Butler, brings into the news one of the most distinguished British artists [sic] of the present day. (Fig. 5) One of the most remarkable things 


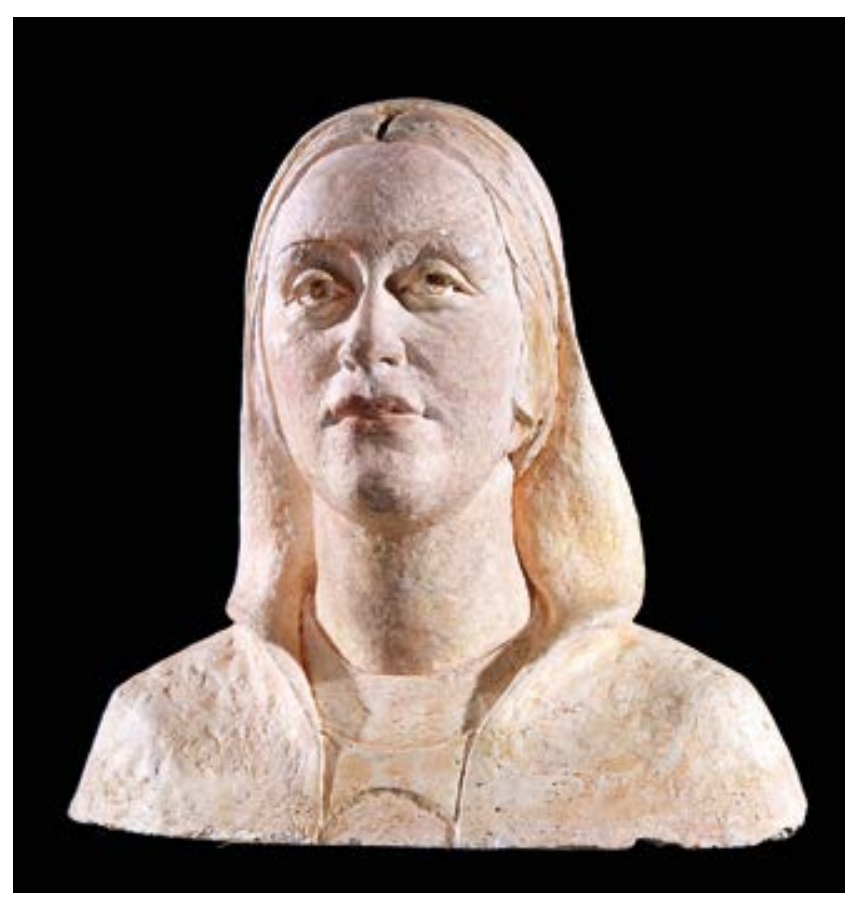

about Margaret Butler is that, like the traditional prophet, she is almost without honour in her own country. It must be five years since she returned from abroad, and since then she has been quietly working in her studio on The Terrace in the midst of a Wellington which, far from feeling honoured by her very presence, has scarcely even been aware of it.

Till the latest purchase, Margaret Butler has been represented in the hall of sculpture at the National Art Gallery by one immature study, done before she left New Zealand to study abroad. From that time Margaret Butler became a name known and honoured in the greatest European galleries. She exhibited every year for nine years in the leading salons in Paris and at the Royal Academy in London.

Her work has been admired and approved by such great sculptors as Bourdelle, Despiau, and Driver [sic $]^{24}$ and she has received favourable notices from many of the best art critics of the day. Typical of the praise her work evoked wherever it was shown is this extract from the "Vienna Herald,"25 when she was living in that city in 1932:-

"It is difficult to define the quality of great art, just as difficult as to define the quality of this rare artist.
Her work lives and glows; it is imbued in all her portraits with a fine and mysterious life of its own, which the French call 'interieur,' and the Germans [V]erinnerlicht.

"There is a serenity and purity, divorced from every superfluous touch, about all her sculptures, which marks the superb artist. She goes to simple types or she takes most frequently as model a countenance expressive of a single, straight-forward thought or tendency of mind. Her analysis of character is profound as her sympathies are broad. She depicts the sublime poetry and tragedy of peasant lives with very simple modelling. Her characters are eloquent, intense, and concise. These are rare qualities in the artist nowadays, and their very simplicity places them outside the ken of "the moderns.'

"On the other hand, Margaret Butler, in the sense that she reflects the beauties and tragedies of the human soul, which do not fade or change with time, is just as modern as anyone who ever prated dadaism. She has that clarity of vision born of true sincerity. Every one of her portraits confronts us with a life, impels us to the study of man, and we are the richer for the experience. This is great art."

...It is said of Margaret Butler that she has immortalized types of Brittany, with a surety and perspicacity worthy of Meuniere [sic], ${ }^{26}$ though there is nothing similar in their methods except that each has touched the soul of the labourer and the soil. The same quality of conception of the spirit of a people is reflected in her more recent Māori studies. One, a Māori Madonna, can be seen in the Catholic section at the [New Zealand] Centennial Exhibition. ${ }^{27}$

(Figure 6) A bust, "Rosalie," in the fine arts section of the women's court at the exhibition, has already aroused considerable interest and admiration.

Perhaps the reason why New Zealanders have scarcely been aware of the genius in their midst lies in the fact that they have had very little opportunity to know anything of Margaret Butler's work. The new acquirement [sic] for the National Art Gallery shows an awakening on the part of those in whose power it lies to reveal to an art-hungry public the best productions of its own country's artists.

In the meantime, working steadfastly and quietly in her roomy studio, Margaret Butler hides herself from all 
publicity. This brilliant sculptor, to whom fame in the great art-loving countries of the old World came as her natural due, would not seek honour in her native land. When she left Vienna they said of her: "Vienna is honoured to have had this sterling artist from that distant new world of New Zealand in her midst, and we sincerely hope she will often come again, and remain longer here."

Now that they are able to have a first real taste of Margaret Butler's work, it is to be hoped that New Zealanders will appreciate their brilliant countrywoman sufficiently to encourage her to stay here for many honoured years.

\section{MĀORI LEADERS}

\section{[Evening Post (16 November 1940): 13]}

WORK FOR MINISTERS

SUGGESTION BY MINISTER

The suggestion that the Centennial year should not be allowed to close without the talent of New Zealand sculptors being set to work to preserve for future generations the likenesses of living Māori leaders was put forward today by the Minister of Education (Mr [Rex] Mason), before he unveiled the memorial plaque and tablet to Professor H. B. Kirk in the new biology block at Victoria University College. ${ }^{28}$ (Figure 7) The Minister said that the pakeha was proud to share the name of New Zealand with the Māori.

The Minister asked whether New Zealanders sufficiently appreciated and encouraged their own New Zealand artists, and thought that the talent of Dominion sculptors might be employed to a greater degree than at present. He took pride in the fact that the plaque and tablet were the work of New Zealanders, the former was modelled by Miss Margaret Butler, whose work had been accepted in the Paris Salon, and the tablet was made by another New Zealander, Mr. R. J. Hill.

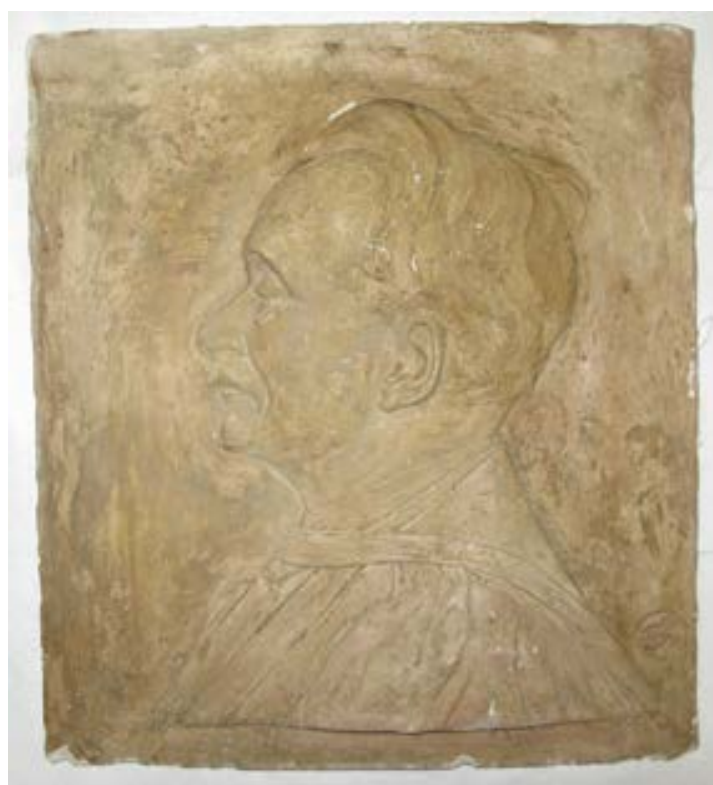

Figure 7: Margaret Butler, Professor H. B. Kirk, 1940 , plaster, $400 \times 360 \mathrm{~mm}$. Museum of New Zealand Te Papa Tongarewa. Gift of the New Zealand Academy of Fine Arts, 1950.

\section{RECOGNITION OF ARTISTS}

[Evening Post (27 November 1940): 6]

(To the Editor.)

Sir, -May I raise a point in connection with your report of that interesting and encouraging ceremony, the unveiling of a plaque to Professor Kirk in Victoria University College? ${ }^{29}$ In your report of the ceremony, you did not mention the name of the artist who made the memorial, Miss Margaret Butler, nor was her name included in the letterpress under the illustration. You did mention her elsewhere, but I don't think this is quite the same thing. I raise the point as a matter of principle. There is a disposition in this country to give artists less than their due. Sometimes the names of givers of works of art are a good deal more prominent than the names of the artists who, after all, do count for something...

I notice that the Professor Kirk plaque bears Miss Butler's initials, neatly inscribed in the corner. May I ask if there will be any further indication to students and visitors, now and in the future, that the memorial is the work of Miss Butler? Will we have people asking who "M.B." is?.. 


\section{REFERENCES}

Art Lover. Letter to the editor, Evening Post, 9 February 1937: 8.

"Art Notes." Art in New Zealand 38 (1937): 225-

Blackley, Roger. Te Mata: The Ethnological Portrait (Wellington: Adam Art Gallery/Victoria University Press, 2010)

B.W.S. "Brilliant Work. New Zealand Sculptor's Achievements. Margaret Butler. Lack of Recognition in Own Country." Dominion, 30 November 1939: 6.

"The Catholic Pavilion." Dominion, 2 February 1940: 11.

"Clever Sculptress: New Zealand Girl." Evening Post, 5 September 1933: 11.

Connors, E. Letter to the editor, Evening Post, 5 February 1937: 6.

Duggan, Eileen. Papers. Archdiocesan Archives, Wellington Catholic Centre.

Dunn, Michael. New Zealand Sculpture: A History. Auckland: Auckland University Press, 2008.

Exhibition of paintings, drawings and sculpture by artists of the British Empire overseas, May 8th-29th, 1937: representative work by artists of Australia, Canada, India, New Zealand \& South Africa at the Royal Institute Galleries (London: Royal Institute Galleries, 1937).

"Here and There": 'Five O'Clock' Party." Evening Post, 6 October 1933: 18

John, Prester [Charles Marris]. "Open Letter to the Editor and Publishers of Art in New Zealand." Art in New Zealand 38 (1937): 195.

Levy, Mark. Letter to the editor, Evening Post, 9 March 1937: 8.

McAloon, William, ed., Art at Te Papa. Wellington: Te Papa Press, 2009
"Maori Leaders. Work for Ministers. Suggestion by Minister." Evening Post, 16 November 1940: 13.

"Margaret Butler Returns", Art in New Zealand 23 (1934): 160-163.

Mulgan, Alan. Letter to the Editor, Evening Post, 27 November 1940: 6.

"Ourselves." Art in New Zealand 41 (1938): 5.

Perplexed. Letter to the editor, Evening Post, 27 February 1937: 8.

Stocker, Mark. "'Our local lady Praxiteles': Margaret Butler and her Sculpture." Art New Zealand, 81 (1996): 74-79, 87.

Stocker, Mark. "Butler, Margaret Mary," first published in the Dictionary of New Zealand Biography, v. 4, 1998. Te Ara - the Encyclopedia of New Zealand, http://www.TeAra.govt.nz/en/biographies/4b55/butler-margaret-mary [accessed 25 June 2017].

Stocker, Mark. Francis Shurrock: Shaping New Zealand Sculpture. Dunedin: Otago University Press, 2000.

Stocker, Mark. "Pakeha Praxiteles: The Sculpture of Margaret Butler." Melbourne Art Journal 6 (2003): 93-106

Stocker, Mark. "'Give us peace in our time, o Lord': W. T. Trethewey's War Memorial in Christchurch, New Zealand." Burlington Magazine, 157 (2015): 776-780.

Stocker, Mark. "Margaret Butler: An Invisible Sculptor?" http://blog.tepapa.govt.nz/2016/03/14/ margaret-butler-an-invisible-sculptor/, 14 March 2016.

T.-S. [François Thiébault-Sisson]. "Art et Curiosité: Margaret Butler," Le Temps, 16 June 1933: 4.

"Work for Science. Professor H. B. Kirk. Memorial Unveiled. A High Tribute." Evening Post, 16 November 1940: 13.

\section{ENDNOTES}

1 For Trethewey, see Michael Dunn, New Zealand Sculpture: A History (Auckland: Auckland University Press, 2008): 44-49; Mark Stocker "'Give us peace in our time, o Lord': W. T. Trethewey's War Memorial in Christchurch, New Zealand," Burlington Magazine, 157 (2015): 776-780.

2 For discussions of earlier, predominantly ethnographic studies of Mãori by the sculptors Allen Hutchinson and Nelson Illingworth, see Dunn, New Zealand Sculpture (2008): 36-39; Roger Blackley, Te Mata: The Ethnological Portrait (Wellington: Adam Art Gallery/Victoria University Press, 2010).

3 Dunn, New Zealand Sculpture (2008): 41.

4 Dunn, New Zealand Sculpture: (2008): 43.

5 Mark Stocker, "'Our Local Lady Praxiteles': Margaret Butler and her Sculpture," Art New Zealand, no. 81 (1996): 74-79, 87; Mark Stocker, "Pakeha Praxiteles: The Sculpture of Margaret Butler," Melbourne Art Journal, no. 6 (2003): 93-106; Mark Stocker, "Margaret Butler: An Invisible Sculptor?" http://blog.tepapa.govt. nz/2016/03/14/margaret-butler-an-invisible-sculptor/, 14 March 2016; Mark Stocker, "Butler, Margaret Mary," from the Dictionary "Bu Ner, Margaret Mary," from the Dictionary ( clopedia of New Zealand, http://www.TeAra. govt.nz/en/biographies/4b55/butler-margaret-mary (accessed 8 May 2017)

6 Quoted in Stocker, "Pakeha Praxiteles," (2003): 102.

7 Quoted in Mark Stocker, Francis Shurrock: Shaping New Zealand Sculpture (Dunedin: Otago University Press, 2000): 9. This situation applied to patronage, critical attention and reputation alike.

8 Michael King, e-mail message to the author, 7 August 2002.

9 Quoted in William McAloon, "Introduction", Art at Te Papa, ed. William McAloon (Wellington: Te Papa Press, 2009): 7. Favoured artists tended to be on the more conservative rather than experimental side of 'International', i.e. British art e.g. Philip Cof Inder Laura Knight, British art, e.g. Philp Connard, Laura Knight, Alfred Munnings and Philip Wilson Steer. This reached an extreme point with the use of a substantial part of a government donation to purchase a portrait of the former Governor-General, the late Earl Jellicoe, by the ca- pable but highly conservative society painter Reginald Eves. See McAloon, p. 8.

10 For Mulgan, see Lawrence Jones, "Mulgan, Alan Edward," from the Dictionary of New Zealand Biography. Te Ara - the Encyclopedia of New Zealand, http://www.TeAra.govt.nz/ enthiographies/4m67/mulgan-alan(accessed 8 May 2017)

11 Marris was literary editor of Art in New Zealand. For his biography, see Stephen D. Hamilton, "Marris, Charles Allan," from the Dictionary of New Zealand Biography. Te Ara - the Encyclopedia of New Zealand, http:// www.TeAra.govt.nz/en/biographies/4m $40 /$ marris-charles-allan (accessed 8 May 2017)

12 The Butler si mous Am rican monologists of the era, Ruth Draper (1884-1956) at Margarets studio, on a New (1884-1956) at Margaret's studio, on New Zealand tour. See "Here and There: 'Five O'Clock' Party," Evening Post (6 August 1938): 18.

13 Archdiocesan Archives, Wellington Catholic Centre, Eileen Duggan Collection. Margaret Butler to Eileen Duggan, 2 September 1937. I have been unable to trace this article, despite careful perusal of Duggan's chief outlet, the New Zealand Tablet.

14 Archdiocesan Archives, Duggan Collection, Butler to Duggan n.d. [c. 1946]

15 Evening Post (3 August 1950): 6.

16 Rosalie Tobia was the patronne of a restaurant in Montmartre, Paris, and "the kindheart who maintained the renowned painter [Amedeo] Modigliani, when that virtuoso was unable to maintain himself." See "Margaret Butler Returns," Art in New Zealand, no. 23 (1934): 161-162.

17 See Exhibition of paintings, drawings and sculpture by artists of the British Empire overseas, May 8th-29th, 1937: representative work by artists of Australia, Canada, India New Zealand \& South Africa at the Royal Institute Galleries (London: Royal Institute Galleries, 1937). The New Zealand selection was monopolised by painters and included works by W. H. Allen, Ida Carey, Russell Clark, R. N. Field, Roland Hipkins, Marcus King and James Turkington, all of whom were considerably younger than Butler. See "Art Notes," Art in New Zealand, 38 (June 1937): 225-226. 
18 The critic's name was François Thiébault-Sisson (1856-1936) and is repeatedly spelled incorrectly. For his review, see his "Art et Curiosité: Margaret Butler," Le Temps (16 June 1933): 4. Although he had championed Edga Degas as a sculptor and had earlier been the author of the significant Claude Monet: An Interview (1900), the poverty of French art historiography is reflected in the absence historiography is reflected in the absence of

fly reasonable. Th Sea Nymph is a small, rather sentimental statuette, carved in marble and atypical of the 'mature' Butler that was to come.

20 For Mary Murray Fuller, see McAloon, Art at Te Papa (2008): 7-8. The painting in question is probably Philip Connard, Dieppe, purchased for 350 guineas by the New Zealand Academy of Fine Arts in 1935

21 'Prester John' (Marris) is referring to Antoine Bourdelle. He and other writers sometimes underestimated Butler's age, possibly because of gallantry, but more likely due to her animated features. See for example "Clever Sculptress: New Zealand Girl," Evening Post $(5$ September 1933): 11, which states: "The young sculptor is unusually gifted." Butler was aged sculptor is unusually gifted. "Butler was ag'
50 at the time. The previous 'controversial' 50 at the time. The previous 'controversial
item was Marris's criticism of newspaper item was Marris's criticism of newspaper "Lamorna" Birch, who had recently visited New Zealand.

22 This description relates to La Nouvelle Zélande.
23 Butler's exhibits at the Salon des Tuileries in 1938 were La Nouvelle Zélande (284) and Une petite fleur sauvage (285)

24 Léon-Ernest Drivier (1878-1951), French sculptor and illustrator.

26 Constantin Meunier (1831-1905), Belgian sculptor.

27 See "The Catholic Pavilion," Dominion (2 February 1940): 11.

28 For Kirk, see John T. Salmon, "Kirk, Harry Borrer," from the Dictionary of New Zealand Biography. Te Ara - the Encyclopedia of New Zealand, http://www.TeAra.govt.nz/en/biographies/2k9/kirk-harry-borrer (accessed 8 May 2017). Kirk enjoyed the rare distinction of being memorialised within his lifetime in Butler's bronze plaque, her last recordin Bule's bronze plaque, her lastrecordentrance foyer of the original Kirk building (now Old Kirk) and was relocated to New Kirk in 1972. Te Papa's plaster portrait is the model for Butler's cast.

29 Alan Mulgan, the author of this letter, was referring to "Work for Science. Professor $\mathrm{H}$. B. Kirk. Memorial Unveiled A High Tribute" Evening Post (16 November 1940): 13. 